\title{
An Ayurvedic Review on Madatyaya W.S.R Alcoholism
}

\author{
*Dnyaneshwar Kantaram Jadhav \\ Shree Dhanwantari Ayurved medical college, India
}

Submission: March 22, 2017; Published: March 27, 2017

*Corresponding author: Dnyaneshwar Kantaram Jadhav, Shree Dhanwantari Ayurved medical college, Mathura, India, Tel: 08451834859; 9664045849; Email: dj85015@gmail.com

\section{Introduction}

In Ayurvedic samhita Madya Varga explained under one of 12 Ahara Varga. It is used as Ahara Dravya (Food Adjunct), as Anupana (After Drink) or as Aoushadhi (Medicine). In sushrut Samhita there is reference of it is also used for Sandnyaharana (Anesthesia) in Shastra Karma (Surgeries). On the basis of use, Madyais classified into two types- as medicine and as beverage. it is further classified into 5 types depending on method and raw material used viz; Asava, Arishta, Sura, Varuni, Sithu. Out of that first two are used for medicine \& remaining as beverages. Madya (Alcoholic Beverages) is one which produces Mada (Excitement). When consumed with proper rules about quantity, time and procedure, it gives happiness, strength, reduces fear, strain and act a as Amrut (Nector) for the body.But the same when consumed without following these rules it results in Madatyaya.

\section{Materials and Methods}

For the present review detailed literary study is performed. The content and references are analysed from Charak, Sushruta and Vagbhatta. Also relevant references are taken from other Ayurvedic, modern's texts and research articles.

\section{Literary Review}

i. Madatyaya Nidan Laxan and Chikitsa is described in 24th chapter of Charak Chikitsa Sthana.

ii. Panatyayapratishedha is described in 47th chapter of Sushrut Uttaratantra. Treatment is also given according to these conditions.

iii. In Ashtangahriday Madatyaya Nidana is described in Nidana Sthana $6^{\text {th }}$ chapter. In the same chapter Mada, Murcha and Sanyasa is also described. Chikitsa of Madatyaya is described in Chikitsa Sthana, $7^{\text {th }}$ chapter.

iv. In Kashyapa Samhita, Madatyaya is described in Chikitsa Sthana after chapter on Krumi. In this text, the attributes of Madya, ill effects of Madya and their treatment are described with special reference to pregnant woman and infants. In Madhava Nidana, Madatyaya is described after description of Krumi Nidana and followed by Daha Nidana. In this text, Sushrut version is followed.

v. In Bhavaprakash, Madatyaya is described in Madhyamakhanda after description of Murcha, Bhram, Nidra, Tandra and Sanyas Adhikarana and followed by Daha Adhikarana. Sushrut version of Panatyaya is followed and some formulations along with treatment principles are discussed. In Yogaratnakar, Madatyaya Adhikara is described after description of Murchadhikara and followed by Daha Adhikara.

\section{Madatyaya}

Madatyaya compromises of two words Madaa and Atyay. Mada means Harsh (Excitement) Atyay [1] means Atikrama (excess). This over excitement is caused by excess consumption of Madya. Depending on the involvement of the Dosha, its toxic effects are occurs $[2,3]$.

\section{Types of Madatyaya}

Madatyaya are tridoshajvhuadhi. Its types named on Dosha which is dominating in presenting the symptoms.

A. Charak [4]: Charak explains types of Madatyaya as Vatapray, Pittapraya and Kaphapraya and considers the disease as Tridoshaja.

\section{1) Vataja Madatyaya [5]}

a. Nidana: If a person is excessively emaciated because of Krodha, Shoka, Bhaya, Vyavaya, Chankramana, Sahasa, while eating Ruksha type of food, less quantity of food or limited quantity of food, drinks Madya at night which is excessively fermented, then this leads to the impairment of his Nidra and Vatapray type of Madatyaya instantaneously develops. 
b. Lakshana: The Vatapray type of Madatyaya is characterized by the following symptomatology-Hikka, Shwasa, Shirah Kampa, Parshva Shula, Prajagara and Bahupralapa. Kashyapasays that in Vatika type of Madatyaya patient will be in Unmattavastha.

\section{2) Pittaja Madatyaya [6]}

a. Nidana: If a person, indulging in food that is Amla, Ushna and Teekshna, having wrathful disposition and having liking for excessive exposure to the fire and sun, drinks excess quantity of Madya that is Teekshna, Ushna and Amla, then he suffers from the Pittapraya type of Madatyaya.

b. Lakshana: Pittapraya type of Madatyaya is characterized by symptoms like Trishna, Daaha, Jvara, Sweda, Moorcha, Atisara, Vibhrama and Haritavarna.

\section{3) Kaphaja Madatyaya [7]}

a. Nidana: If a person who is habituated to Madhura, Snigdha and Guru Ahara, who does not perform Vyayam, who takes Diwaswap and who indulges in Sukhaseenata, excessively drinks Madya which is not an old one or which is prepared of Guda, and Paishtika, then he immediately develops Kaphapraya Madatyaya.

b. Lakshana: Kaphapraya Madatyaya is characterized by Chhardi, Aruchi, Hrillasa, Tandra, Staimitya, Gaurava.

\section{4) Sannipataja Madatyaya}

a. In Sannipataja Madatyaya all or some of the above said features of three individual Dosha can be seen.

b. Lakshan in Sannipataja Madatyaya-Shareeradukham, Balavatsammoha, Hridayavyatha, Aruchi and PratataTrishna, JwaraSheetoshnalakshana, Shirokampa, Jrumbha, Sphuranam, Veepanam, Shrama, Urovibandha, kasa, Hikka, Shwasa, Prajagara, ShareeraKampa, Karnakshimukharoga, Trikagraha, Chhardi, AtisaraandHrulasa, Bhrama, Pralapa.

B. Sushrut: According to Sushrut, the adverse effects of chronic usage of Madya against the rules and regulations prescribed for Madya intake are classified in to four types. They are Panatyaya, Parmada, Panajeerna and Panavibhrama. Sushrut [8] used Panatyaya term in the place of Madatyaya, and accepts 4 types of Panatyaya viz. Vatakrita, Pittakrita, Kaphakrita and Sarvakrita.

1) Panatyaya [9]: Panatyaya is divided into four types depending upon the characteristic features of Dosha predominance.

a. Vatika Panatyaya: It is characterized by Stambha, Angamarda, Hridayagraha, Toda, Kampa and Shiroruja.

b. Paittika Panatyaya: It is characterized by Sweda, Pralapa, Mukhashosha, Daha, Murcha and Vadanalochana
Peetata.

c. Kaphaja Panatyaya: It is characterized by Vamathu, Sheetata and Kaphapraseka.

d. Sannipataja Panatyaya: Symptomatology of three Dosha.

2) Paramada [10]: Paramada is characterized by Ushmanam, Angagurutam, Sleshmadhikatvam, Aruchi, Malamutra-Sanigam, Trishna, Shiro and Sandhiruja.

3) Panajeerna [11]: Aadhmanam, Udgiran Amlarasa, Vidahi and other features of aggravated Pitta characterize Panajeerna.

4) Panavibhrama [12]: Panavibhrama is characterized by Hritgatra, Toda, Vamathu, Jwara, Murcha, Kaphasravana and Shiroruja.

C. Vagbhatta: Vagbhat [13] explains 4 types of Madatyaya viz. Vataja, Pittaja, Kaphaja and Sannipataja. Apart from this Dhvamsaka and Vikshaya [14] is also explained.

a. Nidana: If a person, who suddenly stopped drinking Madya, takes recourse to drinking Madya in excess once again, he suffers from Dhvamsakaand Vikshaya.

b. Lakshana: Dhvamsaka: Sleshmapraseka, Kanthasyashosha, Shabdasahishnuta,Atitandraandnidra characterize the Dhvamsaka; Vikshaya: Sammoha, Chhardi, Angaruja, Jwara, Trishna, Kasa, Shirashoola characterise the Vikshaya.

Prognosis: Since a person suffers from Dhvamsaka or Vikshaya who is already emaciated because of his earlier drinking habit, these two diseases are difficult to cure.

\section{How one becomes addicted [2]}

In Charak Samhita, Chikitsa Sthana, Madatyaya chapter the various Awasthas in an individual becoming addicted with Madya is elaborated. Giving an emphasis on the importance of tranquil mind for attaining the highest goals of human life, Charak says, whatsoever is useful after death, whatsoever is good for the present life, and whatsoever is supreme for attaining salvation are based on the tranquillity of the mind of an individual. Madya considerably agitates this mind as a strong wind shakes the tree located on the bank of a river. These people with a Madyalalasa become Madandha and lose all happiness of life.

\section{Duration of severity of Madatyaya/ Panatyaya}

According to Vagbhat and Yogaratnakar the severity of disease Madatyaya will persist for seven or eight days.

\section{Upadrava of Madatyaya [15]}

The complications of Madatyaya-Hikka associated are Jwara, Vamathu, Vepathu, Parshwashoola, Kasa and Bhrama. 


\section{Global Journal of Addiction \& Rehabilitation Medicine}

\section{Asadhya Lakshana [16]}

The following are the characteristics of Asadhya Lakshana: Heenottaraushtiham, Atisheetam, Amandadaham, Tailaprabhasyam, Jihvaushtiha, Dantamasitamvaaneelam, peetenayanarudhirataa (Figure 1).

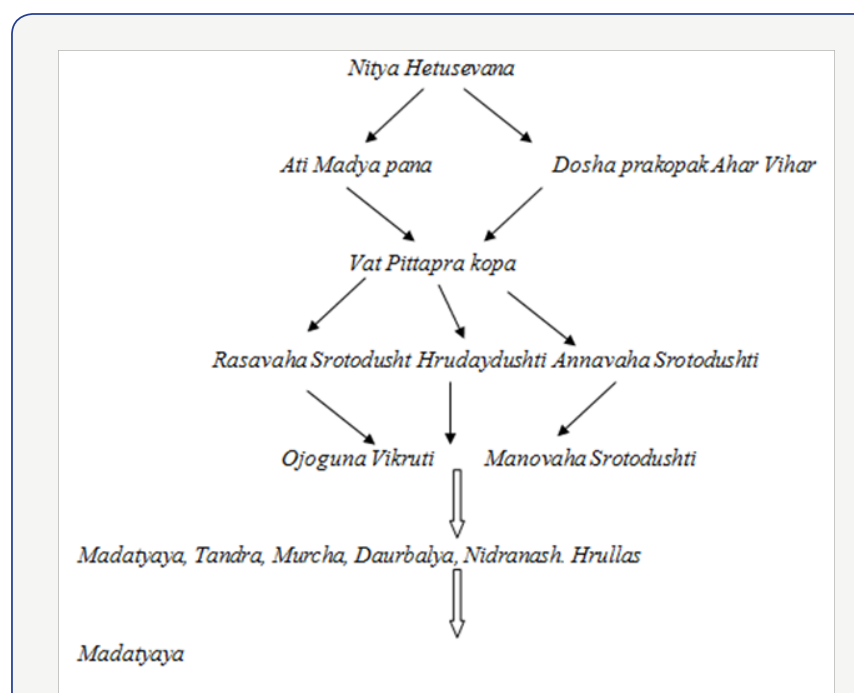

Figure 1: Samanya Samprapti of Madatyaya [3]

\section{Chikitsa of Madatyaya [17]}

According to Kashyapa, Madatyaya is Amaja. That is why while treating Madatyaya, Langhana should be done first. All the types of Madatyaya are of Tridoshaja. Therefore, in the beginning, treatment should be done for the most predominant Dosha. If all the Doshas are equally aggravated, then the treatment should be done first for the location of Kapha, followed by that of Pitta and lastly that of Vata.

The ailments caused by the drinking of Madya in MithyaaAtiyoga -Heena yoga can be cured by taking the Madya in appropriate manner and quantity (Samayoga). Here the same type of Madya or other varieties of Madya can also be given. Intake of excessive Madya which is Teeksha, Ushna, Amla and Vidahi makes the Annaras Utkleda and will be digested improperly which ultimately turns Kshara and causes Antardaha, Jwara, Trishna, Pramoha, Vibhrama and Mada. To correct these ailments, Madya should be administered because when a KsharaDravya gets mixed with a Amla Dravya, the outcome becomes sweet in taste, and Madya is the best among the Dravyahaving Amla Rasa. Madya is Panchrasatmak. These along with other ten Guna Madya has fourteen attributes in total. It is because of this fourteen attributes, Madya stands supreme among all the Amla Rasatmak Dravya. Madya removes the obstruction in the Srotasa, helps in the Vatanuloman, acts as Deepana-Pachana and becomes Satmya, when consumed habitually i.e. Abhyasat. When the obstruction in the Srotasa is removed and Vayu moves downwards, the pain subsides and the ailment caused by intake of Madya gets cured.
For Vatika type of Madatyaya type of Madya (prepared of the paste of cereals) mixed with Beeja Puraka, Vrikshamla, Kola and Dadima, some quantity of Yavaani, Hapusha, Ajaaji and Shrinigavera should be taken along with salt. For Paittika type of Madatyaya Madya prepared from Sharkara or Mardvika type of Madya which is diluted with large quantity of water along with the juice of Kharjura, Mridveeka, Parushaka, Dadima should be given. For Kaphaja type of Madatyaya Vamana Karma and Langhana should be administered. If the patient suffers from Trishna, then the Kashayas prepared of Hribera, Bala, Prishniparni, Kantakaari, Naagara should be given. For Dosha Pachana, Kashaya prepared from Dusparsha, Mustha, or Parpataka should be given.

For Sannipataja Madatyaya, which can be often types [18], according to the Dosha dominance, the appropriate treatment, should be done. When there is involvement of three Doshas with equal dominance, then first treatment should be done for Kapha Dosha followed by Pitta Dosha and Vata Dosha.

\section{Conclusion}

It is concluded that Madatyaya (Alcoholism) is well explained in Ayurveda. Which helps in diagnosis and management depending on the involvement of the Dosha.

\section{References}

1. Manna lal Abhimanyu, Amarkosha of Amara singh, choukhamba Publication, 1999, Trutiya Khanda 3, page no. 204

2. Brahmanandtripathi, Charak Samhita of agnivesha, choukhamba publication, $5^{\text {th }}$ edition, 1998, Chikitsa Sthana 24 , verse no.55, page no.812.

3. Brahmanand tripathi, Charak Samhita of agnivesha, choukhamba publication, Reprint 2004, Sutra Sthana 24 ,verse no.25, page no. 434.

4. Brahmanandtripathi, Charak Samhita of agnivesha, choukhamba publication, $5^{\text {th }}$ edition, 1998, Chikitsa Sthana 24, verse no.90-100, page no.818-819.

5. Brahmanandtripathi, Charak Samhita of agnivesha, choukhamba publication, $5^{\text {th }}$ edition, 1998, Chikitsa Sthana 24, verse no. 89-91, page no.818.

6. Brahmanandtripathi, Charak Samhita of agnivesha, choukhamba publication, $5^{\text {th }}$ edition, 1998, Chikitsa Sthana 24, verse no. 92-94, page no.818.

7. Brahmanandtripathi, Charak Samhita of agnivesha, choukhamba publication, $5^{\text {th }}$ edition, 1998, Chikitsa Sthana 24, verse no. 95-97, page no.819.

8. AmbikadattashastriSushrut Samhita Uttartantra Chaukhamba publication Reprint 2011, 47,verse no.17-18, page no.423

9. Ambikadattashastri Sushrut Samhita Uttartantra Chaukhamba publication Reprint 2011, 47,verse no.18,page no.423

10. Ambikadattashastri Sushrut Samhita Uttartantra Chaukhamba publication Reprint 2011, 47,verse no.19,page no.425

11. Ambikadattashastri Sushrut Samhita Uttartantra Chaukhamba publication Reprint 2011, 47,verse no.20,page no.425

12. Ambikadattashastri Sushrut Samhita Uttartantra Chaukhamba publication Reprint 2011, 47,verse no.21,page no.425

13. Ganesha Garde, Sarth Vagbhata, Anmol Publication, $6^{\text {th }}$ edition, 2003, nidansthan, 6,verse no.14, page no.180 
14. Ganesha Garde, Sarth Vagbhatta, Anmol Publication, $6^{\text {th }}$ edition, 2003, nidansthan, 6,verse no.22, page no.181

15. Ambikadattashastri Sushrut Samhita Uttartantra Chaukhamba publication Reprint 2011, 47,verse no.23, page no. 426

16. Ambikadattashastri Sushrut Samhita Uttartantra Chaukhamba publication Reprint 2011, 47,verse no.22, page no. 425

This work is licensed under Creative

Commons Attribution 4.0 Licens।

DOI: 10.19080/GJARM.2017.01.555563
17. Brahmanandtripathi, Charak Samhita of agnivesha, choukhamba publication, $5^{\text {th }}$ edition, 1998, Chikitsa Sthana 24 , verse no. 107-109, page no.820.

18. Brahmanandtripathi, Charak Samhita of agnivesha, choukhamba publication, $5^{\text {th }}$ edition, 1998 , Chikitsa Sthana 24 , verse no. 189 , page no.847.

Your next submission with Juniper Publishers will reach you the below assets

- Quality Editorial service

- Swift Peer Review

- Reprints availability

- E-prints Service

- Manuscript Podcast for convenient understanding

- Global attainment for your research

- Manuscript accessibility in different formats ( Pdf, E-pub, Full Text, Audio)

- Unceasing customer service

Track the below URL for one-step submission https://juniperpublishers.com/online-submission.php 